\title{
Meta-analysis reveals microevolution in grassland plant species under contrasting management
}

\author{
Journal Article \\ Author(s): \\ Pluess, Andrea R. \\ Publication date: \\ 2013-09 \\ Permanent link: \\ https://doi.org/10.3929/ethz-b-000071574 \\ Rights / license: \\ In Copyright - Non-Commercial Use Permitted \\ Originally published in: \\ Biodiversity and Conservation 22(10), https://doi.org/10.1007/s10531-013-0528-y
}




\title{
Meta-analysis reveals microevolution in grassland plant species under contrasting management
}

\author{
Andrea R. Pluess
}

Received: 24 August 2012/ Accepted: 9 July 2013/Published online: 26 July 2013

(C) Springer Science+Business Media Dordrecht 2013

\begin{abstract}
Grassland species might be under differential selection pressure due to management regimes by man or unmanaged grazers. To investigate microevolutionary changes in plants, I used a meta-analysis and a comparative approach. This analysis incorporates 28 studies on 19 species in 3 paired management regimes with a total of 152 reported trait values resulting in 40 pooled Hedge's $d$ effect sizes on genetic, vegetative and reproductive traits as well as 83 Hedge's $d$ s of 14 specific traits. Of the pooled and specific traits, 60 and $72 \%$ indicated divergent selection pressures within a management regime. The pooled Hedge's $d$ s did not differ among the management regimes. Within mown versus grazed sites, trait groups were affected differently with increased reproductive traits in plants originating from grazed sites. In the other management regimes, the trait groups were affected similarly, except of some specific traits. Longevity, palatability, clonality and biome origin did not explain differences in pooled effect sizes, but tended to explain differences in some specific traits. Overall, general selection patterns were rare probably due to a high heterogeneity of among and within species responses, which might level each other out. Moreover, the number of data points per group of interest is often low and thus, for a final conclusion more studies are needed. Nonetheless, the divergent plant reactions indicate that selection pressures within paired management regimes might be large enough to induce microevolutionary changes in grasslands. Subsequently, the increased variation within species under different management techniques might buffer species persistence in the long term.
\end{abstract}

Keywords Contemporary evolution · Grassland · Habitat selection · Land-use · Review

\section{Introduction}

Species occurring along broad ecological amplitudes are expected to be under divergent selection pressure due to the different environmental cues which they encounter in the

\footnotetext{
A. R. Pluess $(\bowtie)$

Department of Environmental Systems Science, Swiss Federal Institute of Technology Zurich

(ETH Zurich), Universitaetstrasse 16, 8092 Zürich, Switzerland

e-mail: andrea.pluess@env.ethz.ch
} 
contrasting habitats. Indeed, local adaptation along environmental gradients was found in plants and animals (Reznick and Ghalambor 2001; Leimu and Fischer 2008; Savolainen 2011). Environmental gradients might not only be of natural origin but might also be determined by anthropogenic influences. There is recent evidence, that such anthropogenic changes can have microevolutionary consequences (Ashley et al. 2003). The probably most prominent case is the evolution of heavy metal tolerant plants in considerably polluted areas (reviewed in Bone and Farres 2001). Other examples of microevolutionary changes, which are also a byproduct of anthropogenic land-use, include the effects of contrasting management regimes on plants of semi-natural habitats such as grasslands (Fischer et al. 2008). Different ecotypes might emerge due to contrasting management (Reisch and Poschlod 2009). While at local scale within species genetic diversity might thereby decrease, at landscape scale differential selection pressure maintains or even increases genetic diversity, which is an important pre-requisite for further evolutionary changes. The understanding of these microevolutionary processes forms the basis for the preservation of the evolutionary potential of grassland plant species, an actual conservation concern (Pico and van Groenendael 2007).

After the last glacial maxima, natural grassland formed on shallow soils of e.g. outcrops, steep slopes (Poschlod and WallisDeVries 2002) and above the tree line in Central Europe. Since the Neolithic period, livestock husbandry in forests fostered herbaceous species and triggered the development of common pastures which expanded throughout Central Europe during the Roman Empire (Pott 1996). The continuation of agricultural traditions maintained the grasslands for centuries (Bätzing 2003). Due to the regular reduction of biomass, woody species are mostly excluded. Natural grazers and re-occurring fire regimes maintain grasslands in other regions of the world, such as semi-dry areas and the African Savannah (Norton-Griffiths 1979). Today, traditional grassland management, especially in Central Europe, is under economic pressure and leads to intensification but also abandonment of formerly extensively used grasslands (Lachat et al. 2010; Stöcklin et al. 2007). In all grasslands over the world, selection pressure on plant species might change due to the intensity of disturbance induced by haying, livestock or unmanaged, free-ranging grazers as well as the abandonment of the former land-use.

Management regimes have the potential to shape grassland plant communities (Poschlod and WallisDeVries 2002). At the species level, evolution might be influenced by the management regime because each regime represents another set of potential selection pressures. The applied managements might thereby promote traits such as the reproductive investment, height and flowering phenology differently within a species. In addition, plant reaction to selection pressures might depend on its life-history traits. For example, grazing will affect non-palatable species less than palatable ones or microevolution might be more rapid in annuals due to their shorter life cycles. Indirect effects of the management have further potential to shape plant traits: The trampling of ungulates disturbs the grounds which enhances seed establishment. This might lead to an increase in genetic diversity within a site, while clonal growth ( $c f$. Silvertown and Charlesworth 2001) might reduce genetic diversity of a species in the long-term (Schmid 1990). Clonality is a life strategy especially favored in environmental conditions where sexual reproductive success is less guaranteed (Callaghan and Emannualson 1985). Clonal growth might therefore be fostered in grasslands which are mown before the seeds mature. Moreover, clonality might enhance competitive ability, an important trait especially in abandoned sites where vegetative cover increases. Traits for competitive ability have been shown to increase before the herbaceous species become eventually outcompeted (Ronce and Olivieri 1997) and locally extinct 
(Fischer and Stöcklin 1997). Overall, local species persistence under contrasting management regimes might be guaranteed via divergent adaptation.

This study aims to investigate if plant species are under divergent selection due to different management techniques as well as natural grazing regimes. Given that trade-offs generally determine plant traits, different plant traits might be affected differently by a given treatment and thus, trait groups and specific traits are compared in this study. Moreover, life-history strategies such as clonal versus non-clonal growth forms or perennial versus annual live cycles might result in a dissimilar selective outcome. Through combining available studies on microevolution in grassland plants under different management regimes, selection patterns are studied. Specifically, this meta-analyses asks if (i) different management/grazing regimes represent selection pressures of different strength; if (ii) sexual reproductive traits might be more affected by the treatment than vegetative or neutral genetic traits, as reproduction is key for population persistence, and if specific traits within one of the aforementioned trait groups are affected differently by the same treatment due to trade-offs; if (iii) plants with contrasting live history traits (clonal vs. non-clonal and annual vs. perennial) or defense mechanisms (palatable vs. unpalatable) are affected differently; and if (iv) selection pressures are similar in grasslands of different biomes. Because the data bases for some of the questions asked was low for a statistical approach, the findings are also discussed in a qualitative comparative way.

\section{Materials and methods}

Data acquisition

In June 2012, studies on the effects of management on herbaceous plant species were searched for on Web of Science (ISI, SCI-Expanded) with a total of 14 combinations of: "genetic diversity or genetic variation" and "land use or management" and "pasture or meadow" $(N=8)$ as well as "genetic diversity or genetic variation" and "land use or management or agriculture" and "grassland" $(N=6)$. A list of 252 articles resulted. This list was expanded with suitable studies found in the reference lists of the included papers. Studies were included if they report measurements of plants originating from two different management regimes and if they report average values, variances and sample sizes or if these values could be calculated based on the presented data. Studies on cultivars were excluded as well as studies on in situ collected data, except for genetic diversity, clonal extent, germination of field collected seeds as well as plant growth in Elytrigia atherica and Veratrum album. Thus, the quantitative genetic dataset comprised primarily of ex situ collected measurements of wild plants grown in common garden experiments. Data was extracted from tables and in some cases from figures using Data Thief (Tummers et al. 2010). The final list contained 28 studies on 19 plant species with a total of 152 trait values measured in two treatments each. The traits covered a wide range from genetic to genecological estimates containing in total 14 specific traits and were grouped into the four trait groups vegetative, reproductive, genetic and heritability traits (Table 1). Per species and management regime, ten combinations included plants originating from one replicate per management type of which six combinations included several plots per replicate. Eleven combinations used three to 29 site replicates per management type (Table 2). 
Table 1 Trait groups and specific traits used for the analyses

\begin{tabular}{|c|c|c|}
\hline Trait group & Trait & Description \\
\hline \multirow[t]{8}{*}{ Vegetative } & AGB & $\begin{array}{l}\text { Weight of above ground biomass or } \\
\text { diameter of clone }\end{array}$ \\
\hline & AGBnumber & Numbers of shoots or leaves \\
\hline & Plant height & $\begin{array}{l}\text { Stem length (often the inflorescence } \\
\text { was explicitly excluded) }\end{array}$ \\
\hline & Leaf size width & Width of the leaf \\
\hline & Leaf size length & Length of the leaf \\
\hline & SLA & Specific leaf area (mass/area) \\
\hline & Nutrient content & $\mathrm{N}$ concentration or $\mathrm{mg} \mathrm{N}$ per tiller \\
\hline & BGB & Weight of below ground biomass \\
\hline \multirow[t]{4}{*}{ Reproductive } & AGB & Weight of reproductive biomass \\
\hline & Flower height & $\begin{array}{l}\text { Length of the stem bearing the } \\
\text { inflorescence }\end{array}$ \\
\hline & Phenology & $\begin{array}{l}\text { Start, peak, end or duration of } \\
\text { flowering }\end{array}$ \\
\hline & Establishment & Percent of germination \\
\hline Genetic & Variability & $\begin{array}{l}\text { Expected heterozygosity, number of } \\
\text { polymorphic markers, percentage } \\
\text { of polymorphic markers, clonal } \\
\text { richness }\end{array}$ \\
\hline Heritability & Heritability & \\
\hline
\end{tabular}

Meta-analysis

For the comparison of the paired management treatments, the effect size Hedge's $d$ (Gurevitch and Hedges 1999) was calculated for each trait using the formula $d=$ $\left(\left(\bar{X}_{\mathrm{t} 2}-\bar{X}_{\mathrm{t} 1}\right) / S\right) J$, where $\bar{X}_{\mathrm{t} 2}$ and $\bar{X}_{\mathrm{t} 1}$ are the trait means in the treatment groups, $S$ is the pooled standard deviation and $J$ is a correction term for sample size. $S$ is calculated as $\left.\operatorname{sqrt}\left[\left(N_{\mathrm{t} 2}-1\right) s_{\mathrm{t} 2}^{2}+\left(N_{\mathrm{t} 1}-1\right) s_{\mathrm{t} 1}^{2}\right) /\left(N_{\mathrm{t} 2}+N_{\mathrm{t} 1}-2\right)\right]$ and $J$ as $1-\left[3 /\left(4\left(N_{\mathrm{t} 2}+N_{\mathrm{t} 1}-2\right)-1\right)\right] . N_{\mathrm{t} 2}$, $s_{\mathrm{t} 2}$ and $N_{\mathrm{t} 1}, s_{\mathrm{t} 1}$ are the sample sizes and standard deviations of the treatment groups. The management combinations were binned into three management regimes: (i) mown versus grazed, (ii) non-managed versus managed containing studies of non-managed versus mown or grazed treatments and (iii) the other managements containing studies on low versus high intensity mown or grazed, fertilized versus non-fertilized as well as old versus young grasslands. The first of each aforementioned management combinations was coded as 'treatment ${ }_{1}$ ' and the second as 'treatment ${ }_{2}$ ' for the calculation of the effect size. The 'nonmanaged' group included sites which were literally not managed or declared to be abandoned or fallow. To allow comparisons of plant reactions across management regimes, the treatment with the assumed higher competition pressure, due to the lower 'management' impact (for the mown sites at least until the mowing event), was determined as the treatment $_{1}$ level.

In a first step, the traits were analyses using the grouping into genetic, vegetative and reproductive traits (Table 1). One measure on heritability was available too, was coded separately and included in the overall analyses. Most studies report several traits within each of these three trait groups as well as for specific traits (for example above ground biomass was separated in blades, sheaths and structure) and thus, using individual 


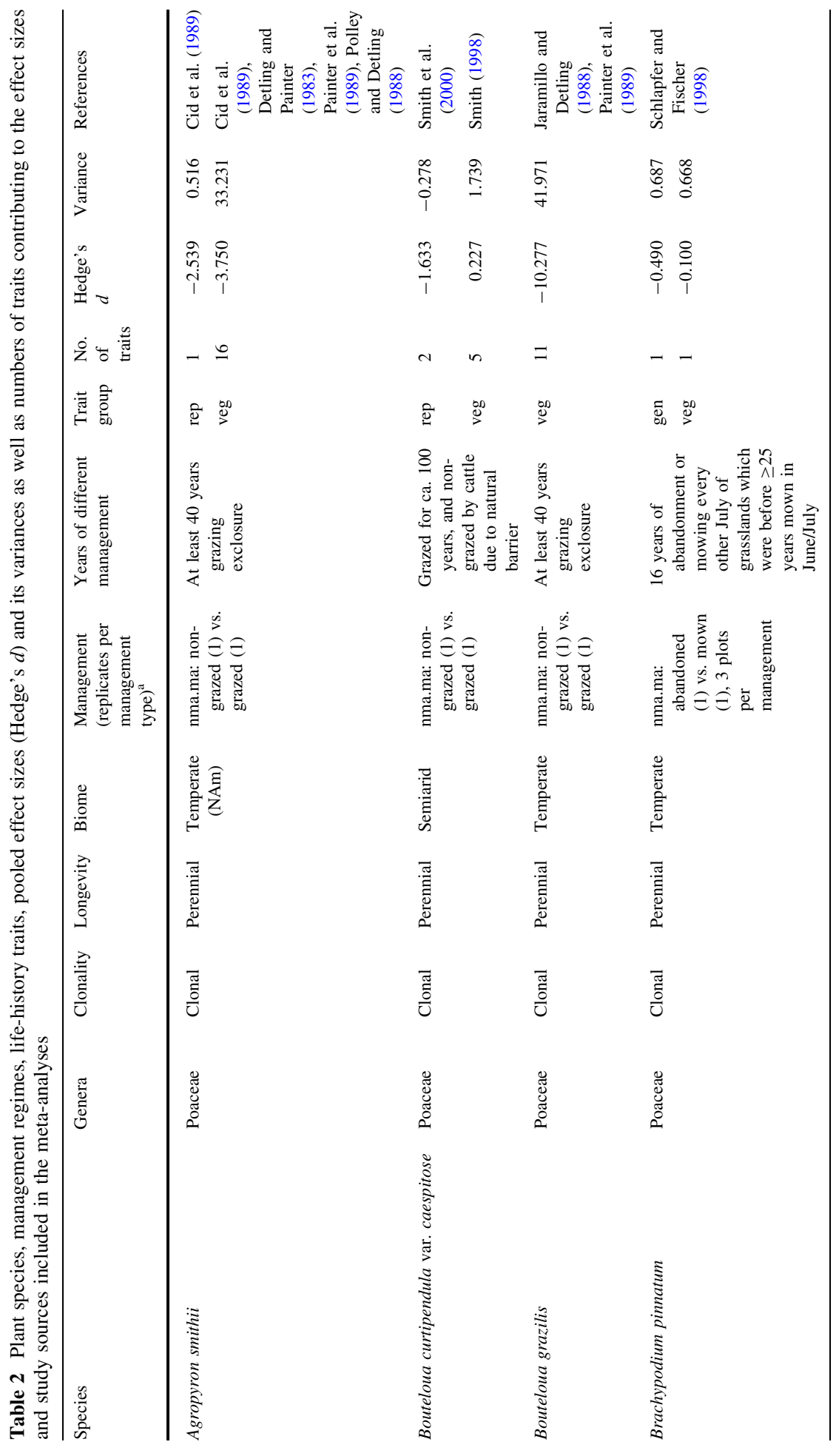




\begin{tabular}{|c|c|c|c|c|c|}
\hline 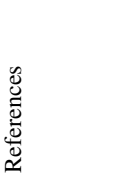 & 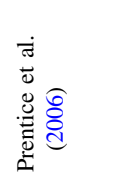 & 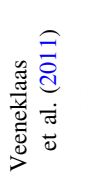 & 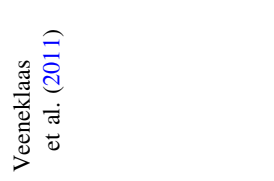 & 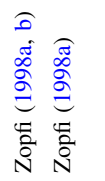 & 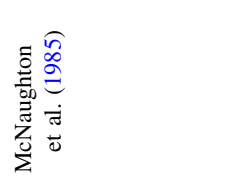 \\
\hline & $\begin{array}{l}\text { I } \\
\text { Oे } \\
0\end{array}$ & $\begin{array}{l}\cong \\
\vdots \\
\circ\end{array}$ & 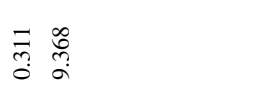 & $\stackrel{n}{m} \underset{0}{\infty}$ & 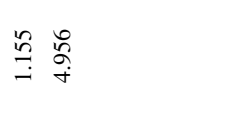 \\
\hline 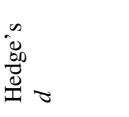 & तू̀ & 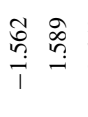 & 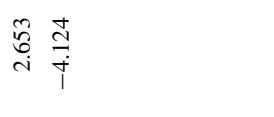 & 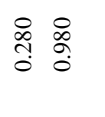 & 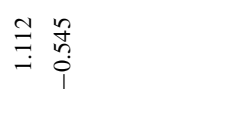 \\
\hline 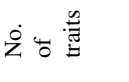 & - & $n+$ & $+\infty$ & 90 & $-m$ \\
\hline 䲩 & $\bar{\Xi}$ & 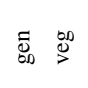 & 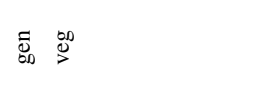 & 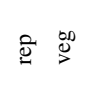 & $\stackrel{\infty}{2} \stackrel{\infty}{\stackrel{0}{0}}$ \\
\hline 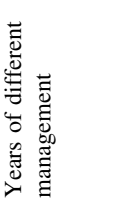 & 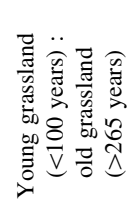 & 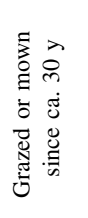 & 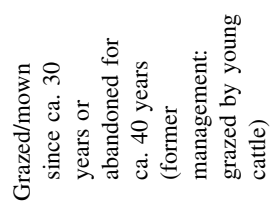 & 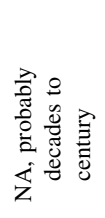 & 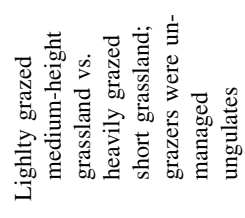 \\
\hline 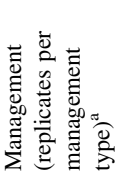 & 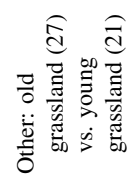 & 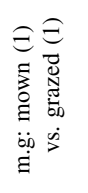 & 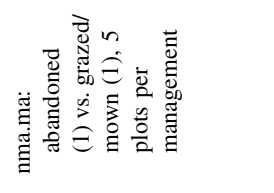 & 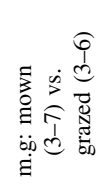 & 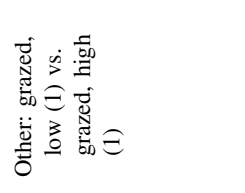 \\
\hline & 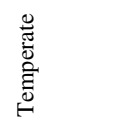 & 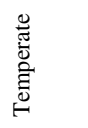 & 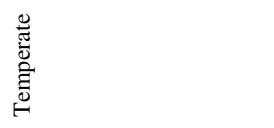 & 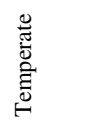 & 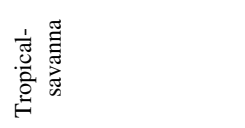 \\
\hline & 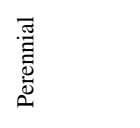 & 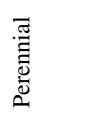 & 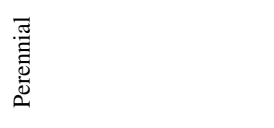 & 嵒 & 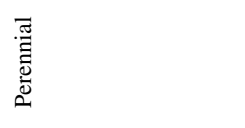 \\
\hline & $\begin{array}{l}\bar{\Xi} \\
\text { Uूँ }\end{array}$ & $\begin{array}{l}\bar{\Xi} \\
\bar{U}\end{array}$ & 苂 & 䯧 & 苂 \\
\hline एँّ & 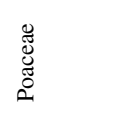 & 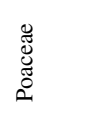 & $\begin{array}{l}\mathscr{\Xi} \\
\stackrel{\Xi}{ \pm} \\
\stackrel{0}{0}\end{array}$ & 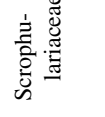 & $\begin{array}{l}\mathscr{\Xi} \\
\stackrel{\Xi}{\Xi} \\
\stackrel{0}{0}\end{array}$ \\
\hline $\begin{array}{l}\frac{\mathscr{0}}{\tilde{u}} \\
\text { के } \\
\text { के }\end{array}$ & 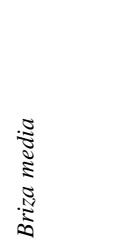 & 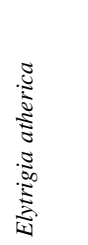 & 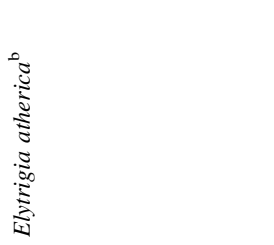 & 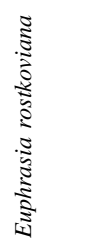 & 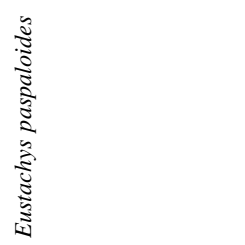 \\
\hline
\end{tabular}




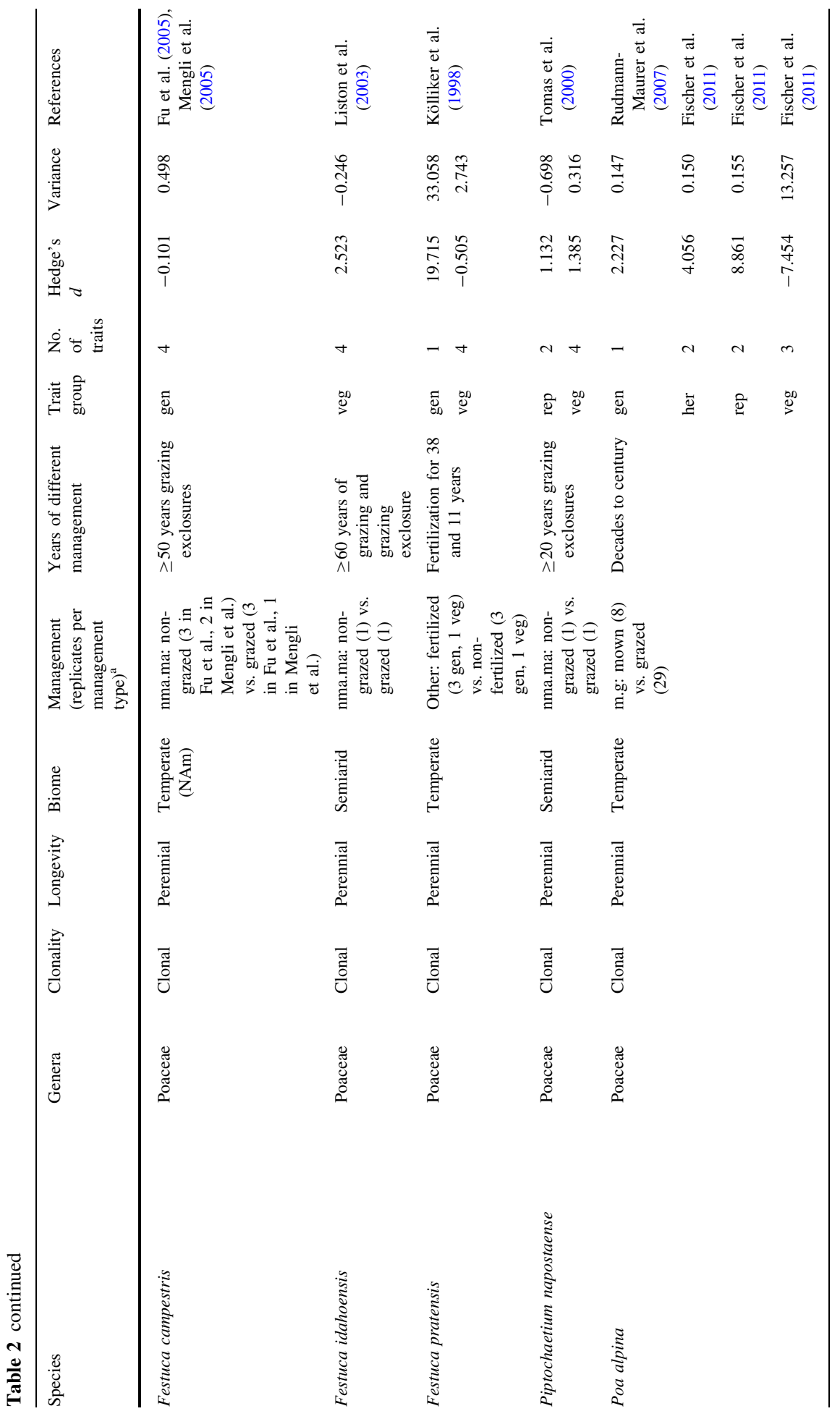




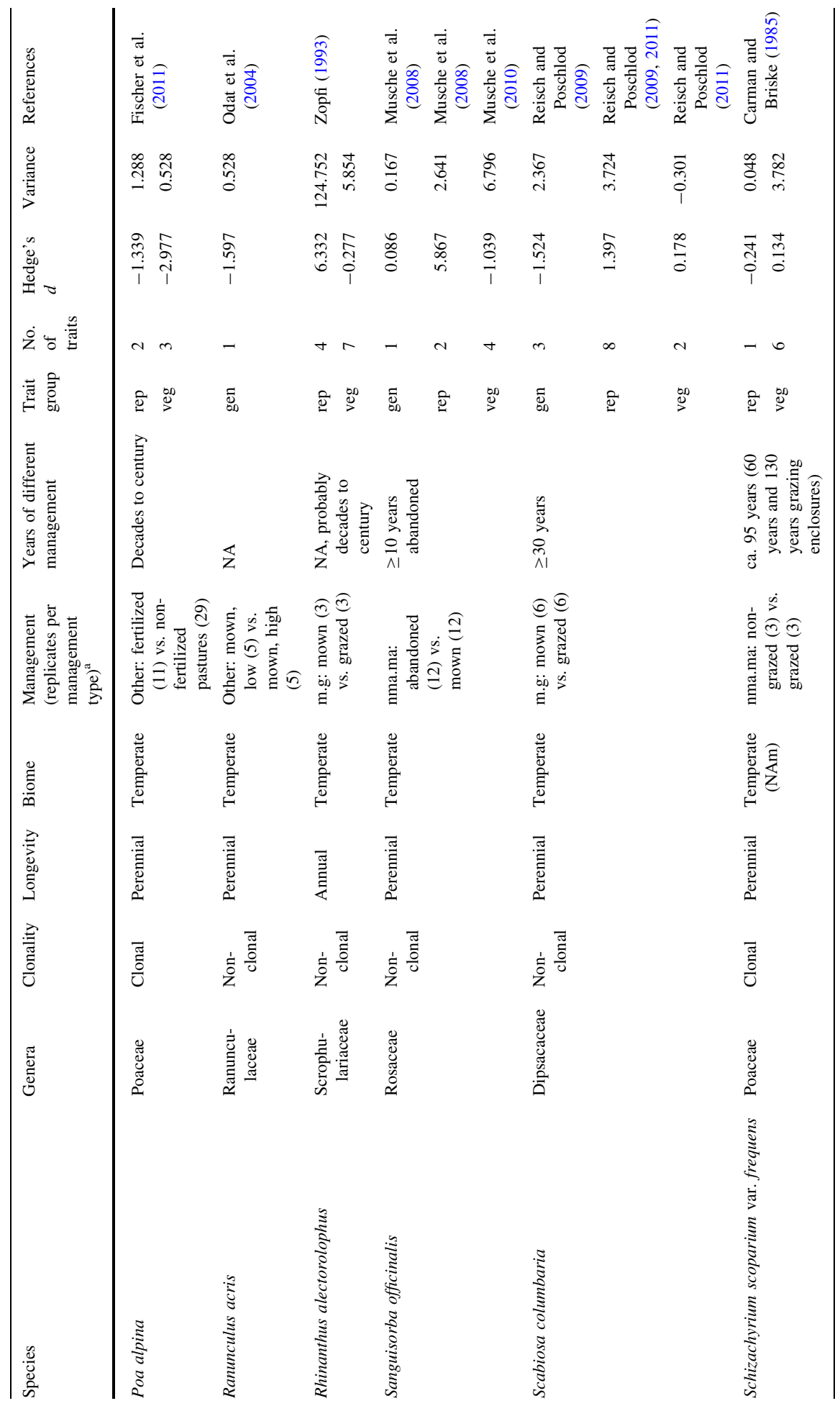




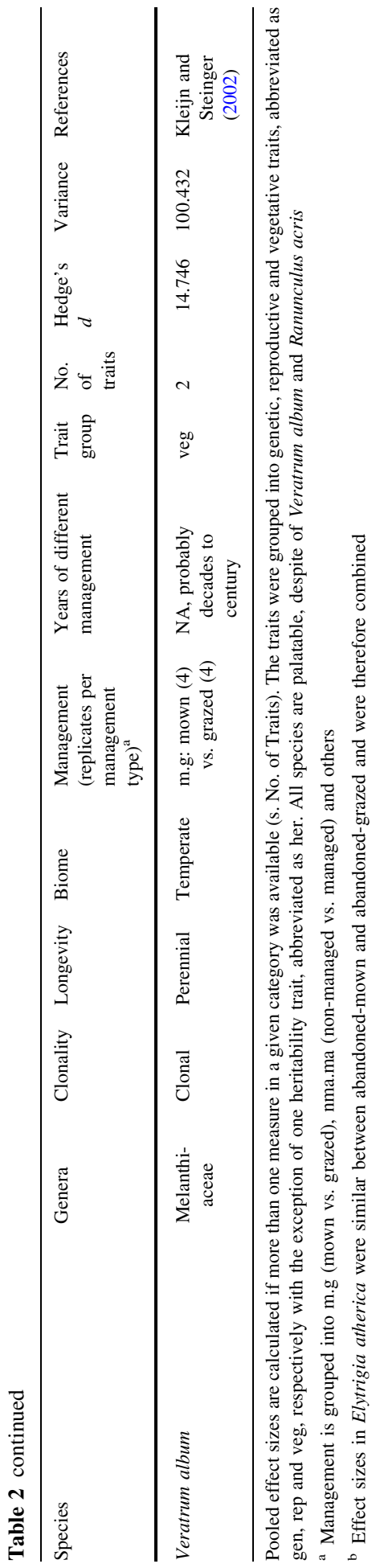


measurements for the analyses would result in pseudo-replication. Therefore pooled Hedge's $d$ and pooled variances across species were calculated for each of these trait groups using random models (hereafter called 'pooled values' even though some Hedge's $d$ represent individual effect sizes if only one trait was available). Thereby studies of the same species and the same origin but published in different papers were pooled, which was the case five times.

Random effect models were used to compare Hedge's $d$ of (1) the different management regimes, of (2) trait groups (genetic, vegetative and reproductive), of (3) life-history traits (clonal vs. non-clonal; annual vs. perennial, palatable vs. unpalatable species) and of (4) the biomes. Furthermore, comparisons of trait groups were also done within each of the three management regimes separately. To test for the significance of the group differences, the Chi square test statistics was applied on the between-group heterogeneity $\left(Q_{\mathrm{b}}\right)$. The $P$ values were Bonferroni corrected to account for the multiple testing across all data points $(N=6)$.

Traits within a trait group might be linked via trade-offs and thereby might level each other out in the pooled effect sizes. Therefore, traits within trait groups and a given management regime were compared (hereafter called 'specific traits', Table 1). To avoid pseudo-replication, one measurement per specific trait and species was retained: If two measures were available, the choice was random. If more measures were available and if they differed in the direction of the effect (i.e. positive, as well as negative effect sizes), one trait was randomly picked in the group representing the majority of the effect direction. This approach instead of the pooled Hedge's $d$ was chosen, as in the latter approach the variance per trait and species cannot be well estimated due to the low number of traits within each specific trait group per species and management regime. For a rough assessment if effect sizes of individual specific traits differ from zero, the $95 \%$ CI was calculated as $d \pm 1.96 \times S$ and it was checked, if zero lays within the CI or not. Within a management group, on average data of $3.2(\mathrm{SE}=0.36)$ species per specific traits were available. Due to this low sample size, the specific traits were compared based only on the inspection of their $95 \%$ bias-corrected CI (see below).

Hedge's $d$ as well as the random effect models were calculated in MetaWin V 2.0 (Rosenberg et al. 1999). The bias-corrected $95 \%$ CI of $d$ was calculated based on 4,999 bootstraps. An effect size was called significantly different from zero if its CI does not include zero. The distribution of the raw as well as the pooled Hedge's $d$ values were visualized with a funnel plot which indicated no publication bias (Palmer 1999; Light and Pillemer 1984). Moreover, Rosenthal's fail-safe number (Rosenthal 1979) was with 3,198 large and above the suggested threshold of $10+5 \times$ number of binned trait values (i.e. $N=30$; threshold $=160$ ), which indicates that many more studies would be needed to falsify a significant result.

\section{Results}

Description of the data-set

The literature survey revealed 40 pooled Hedge's $d$ effect sizes of vegetative, reproductive or genetic trait differences as well as one effect size on heritability between two contrasting grassland managements $(N=18,11,10$ and 1 , respectively; Table 2$)$. The survey of managed versus grazed, non-managed versus managed sites and other management regimes harbored 14, 18 and 8 data points, respectively. The last group contained two 
different levels of mowing or grazing, non-fertilized versus fertilized and young versus old grasslands ( $N=1,2,4$ and 1, respectively). Most data points were collected in temperate areas with 28 in Europe and 5 in North America and a few in semiarid areas and tropical savannas $(N=5$ and 2 , respectively). The effect sizes covered six plant families with the Poaceae being the most prominent one (67.5\% of all data points). In total, 2.6 times more data points for clonal than for non-clonal plants were available $(N=29$ vs. 11$)$. Most data points were drawn from perennial or palatable plants $(N=36$ and 38 , respectively). The variation of the pooled Hedge's $d$ values which are presented in Fig. 1 did not correlate with the number of data points available in a given group (Spearman's rho $=-0.092$, $P=0.73)$.

In total 83 Hedge's $d$ estimates of specific traits were available (Table 3 in Appendix). Within the group of vegetative, reproductive, genetic or heritability traits 53, 19, 10 and 1 estimates, respectively, were present. The three management groups (managed vs. grazed, non-managed vs. managed and other management regimes) were represented by 30, 43 and 10 estimates, respectively.

Overall results

Of the pooled effect sizes, $25 \%$ were negatively and $35 \%$ were positively affected by the 'treatment ${ }_{2}$ ' management while $40 \%$ were unaffected (see numbers in Fig. 1). There was no overall effect of the contrasting treatments on plant traits if all management regimes and plant traits were combined $(d=0.60, \mathrm{CI}-0.19$ to 1.65 ; Fig. 1$)$. The analyses revealed no selection differences among management regimes $\left(Q_{\mathrm{b}}=3.17, d f=2, P=1\right)$, the

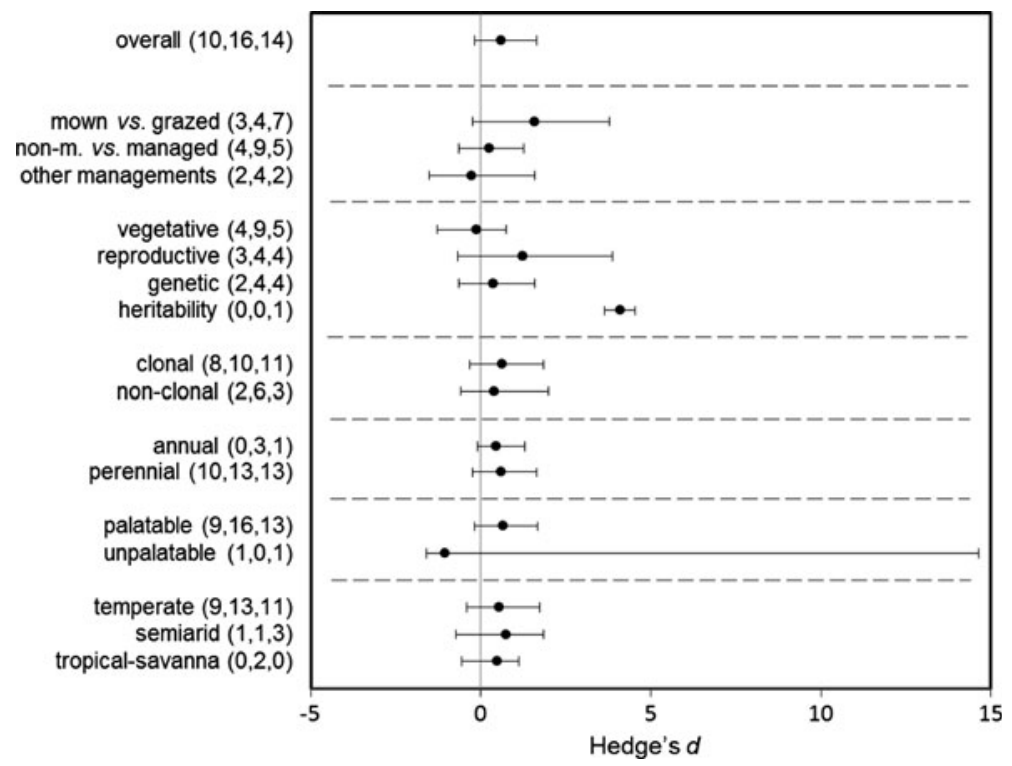

Fig. 1 Pooled effects of contrasting management on plant traits: The pooled effect sizes (Hedge's $d$ values) are pooled further across all/different management regimes, trait groups, the life-history traits and biomes. Numbers of data points per group which are negative, non-different from zero and positive are indicated after the group name. Bars denote the bias-corrected $95 \%$ confidence intervals and the grey, dashed lines indicate the groups which were compared 
vegetative, reproductive or genetic trait groups $\left(Q_{\mathrm{b}}=2.26, d f=2, P=1\right)$, clonality $\left(Q_{\mathrm{b}}=0.06, \quad d f=1, \quad P=1\right)$, longevity $\left(Q_{\mathrm{b}}=0.01, \quad d f=1, \quad P=1\right)$, palatability $\left(Q_{\mathrm{b}}=0.78, d f=1, P=1\right)$ nor biome $\left(Q_{\mathrm{b}}=0.04, d f=1, P=1\right)$. The CIs of these pooled effect sizes included zero, except for heritability which is the pooled effect size of two heritability measures on one species.

At the specific trait level, $38.6 \%$ decreased and $33.7 \%$ increased in the 'treatment 2 ' versus 'treatment ${ }_{1}$ ' management while $27.7 \%$ were unaffected (Fig. 2, Table 3 in Appendix). Within a trait group often several specific traits of a species within a management regime were available. Specific vegetative traits of a given species were influenced differently by the management in eight of seventeen cases, resulting in a pooled vegetative effect size non-different to zero, which indicates a trade-off among vegetative traits (e.g. in Agropyron smithii). Likewise, among reproductive traits, pooled effect sizes were non-different to zero but differed among specific traits in two out of eight cases (e.g. in Euphrasia rostkoviana). On the other hand side, the cumulative effects of specific traits might result in a pooled effect size non-different from zero, even though some or even most effect sizes of specific traits were close to zero (e.g. in vegetative traits of Piptochaetium napostaense).

\section{Effect sizes within management groups}

The three pooled trait groups as well as specific traits might be affected differently in the three management regimes. Therefore, the three management combinations were also analyzed individually. The numbers of sampling points for annuals and unpalatable plant species were low ( $N=4$ and 3 , respectively) as well as for individual traits of non-clonal plants in the treatment group 'other' and thus, these life-history traits were omitted from the following analyses.

In mown versus grazed sites (Fig. 2a), the genetic, vegetative and reproductive traits were affected differently by the managements $\left(Q_{\mathrm{b}}=10.43, d f=2, N=13, P=0.005\right)$. The reproductive traits were increased in the grazed compared to the mown management $(d=4.27$, CI $0.73-8.82)$ while the pooled effect size of the two other trait groups did not differ from zero. Traits of clonal and non-clonal plants were affected similarly by the treatment $\left(Q_{\mathrm{b}}=0.50, d f=1, N=14, P=0.49\right)$. Likewise, if only pooled vegetative traits were considered, there was no treatment effect $\left(Q_{\mathrm{b}}=0.01, d f=1, N=6\right.$, $P=0.94)$. Specific traits indicated that above ground biomass was sometimes increased in grazed plots while plant height and leaf measures were often not affected, as the CIs of the latter often included zero (Fig. 2a, Table 3 in Appendix). Of the specific reproductive traits, a few more data points were increased in grazed versus mown sites ( 5 positive values vs. 3 neutral and 3 negative values). The establishment success was decreased in grazed sites, yet the available individual measures did not differ from zero. The genetic diversity values included a negative, a neutral and a positive measure.

In non-managed versus managed sites (Fig. 2b), the three trait groups were affected similarly by the managements $\left(Q_{\mathrm{b}}=0.12, d f=2, N=18, P=0.95\right)$. The trait groups

Fig. 2 Effects of a mown versus grazed, b non-managed versus managed and $\mathbf{c}$ other management regimes on plant traits. The pooled effect sizes (Hedge's $d$ values, $N=14,18$ and 8 , for a, b and c, respectively) are grouped into the four main trait groups as well as clonal versus non-clonal plants for $\mathbf{a}$ and $\mathbf{b}$. Within the traits groups, specific traits $(N=30,43,10$ for $\mathbf{a}, \mathbf{b}$ and $\mathbf{c}$, respectively) are compared. Numbers of data points per group which are negative, non-different from zero or positive are indicated after the trait name. Bars denote the bias-corrected $95 \% \mathrm{CI}$ and the grey lines indicate the groups which were compared. In cases of sample sizes equal to one, the bars denote the $95 \% \mathrm{CI}$ of the individual $d$ value. ** indicate $P<0.01$ 
(a) Mown vs. grazed

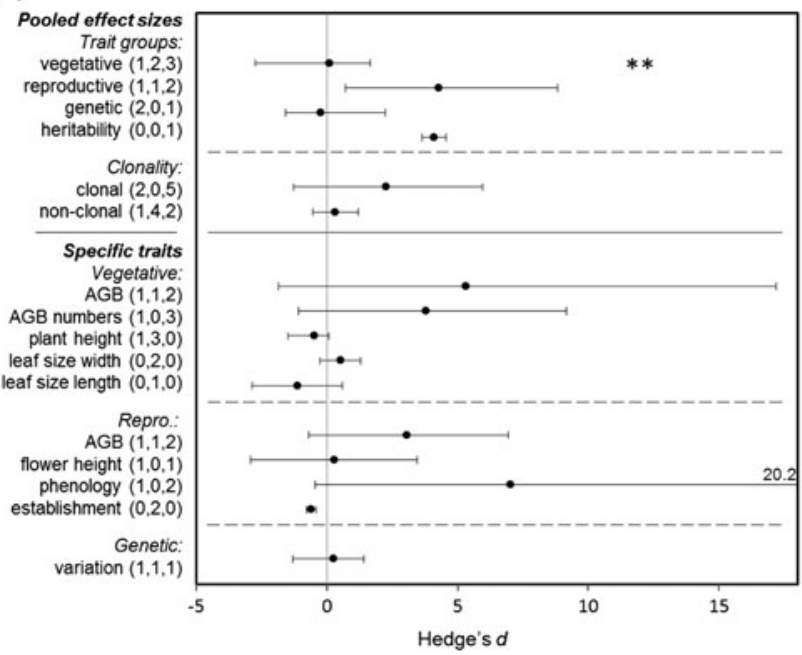

(b) non-managed vs. managed

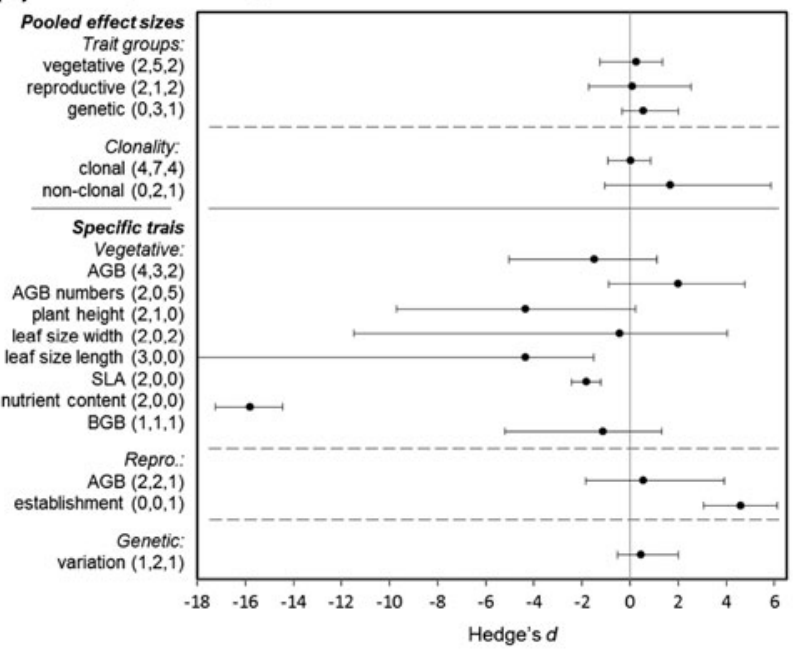

(c) other management regimes

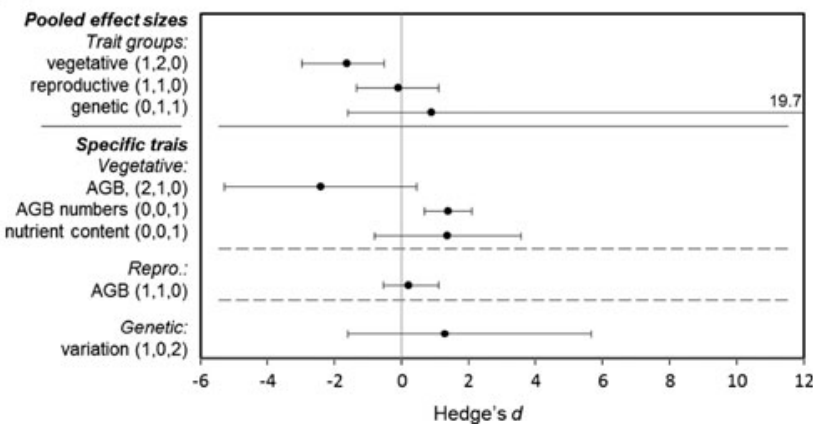


did not differ from zero, even though none of the pooled estimates of the genetic traits were negative. The management had similar effects on traits of clonal versus non-clonal plants $\left(Q_{\mathrm{b}}=1.07, d f=2, N=18, P=0.29\right)$, but again, in the latter none of the pooled estimates were negative. Specific traits indicated that 18 of 33 vegetative measures were increased in non-managed versus managed sites. Specifically, leaf size length, SLA and nutrient content were increased in non-managed sites while plant height tended to be larger in this treatment. Above ground biomass investment into reproduction was non-different from zero while the only establishment value available showed an increased rate in managed sites. The genetic diversity values included a negative, two neutral and a positive measure.

In the other management combinations (Fig. 2c), the three trait groups were affected similarly by the managements $\left(Q_{\mathrm{b}}=1.49, d f=2, N=8, P=0.47\right)$. Yet, the vegetative traits were reduced in the 'treatment ${ }_{2}$ ' compared to the 'treatment ${ }_{1}$ ' management $(d=$ -1.63 , CI -2.98 to -0.52 ). While none of the specific effect sizes of above ground biomass were positive, the only measure for above ground numbers was positive as well as for nutrient content. Above ground biomass investment into reproduction was non-different from zero with a negative and a neutral measure. The genetic diversity values included a negative and two positive measures.

\section{Discussion}

This meta-analysis revealed 60 and $72 \%$ of pooled and specific trait values under divergent influence of the management treatments but these differences can rarely be linked to plant and life-history traits (Figs. 1,2). Specifically, because the results indicate no differences among the three management regimes when all traits are binned, the traits might well be grouped across management regimes to assess differences among trait groups and life-history traits. This revealed that vegetative, reproductive and genetic traits were affected similarly across all treatments. Moreover, individual plants seemed to be affected independent of their characteristics such as longevity, palatability and clonality (Fig. 1). Despite the lack of general selection patterns, a few differences among pooled effect sizes as well as within specific traits arose in a given management-pair. Yet, these differences are based on a few data points only. In general, trait groups within each treatment regime were represented by a non-exhaustive number of observations, increasing the risk that individual measures might dominate the pooled traits as well as reducing the statistical power to detect overall reaction patterns. Indeed, the percentage of data points suggesting divergent selection within a management pair decreased from the specific trait values to the pooled effect sizes (72 and $60 \%$, respectively). Within a trait group, the specific traits were often affected differently, leveling each other out. Given that traits coevolve, specific traits are discussed in conjunction below.

Different sexual investment, establishment success and genetic variation

Instead of seed weights, often above ground investment into sexual reproduction is reported as a fitness proxy. Some of the differences in fitness between managements can be related to habitat quality. In Poa alpina originating from fertilized grasslands, the reproductive biomass was larger alongside an overall larger biomass compared to plants from unfertilized habitats (Fischer et al. 2011). This suggests a selection for genotypes with a greater capacity to absorb nutrients. Sanguisorba officinalis produced lighter seeds in 
abandoned versus mown sites probably due to the lower habitat quality of abandoned sites where competition for light is increased (Musche et al. 2008). Furthermore, P. alpina and Rhinanthus alectorolophus invested more into reproduction if they originate from grazed compared to those originating from mown sites (Zopfi 1998a; Fischer et al. 2011) which might be linked with the grazers. The disturbance by grazers creates open patches which are expected to be save sites for seedling recruitment. Reproduction via seeds might thereby be more frequent leading to a higher abundance of fecund individuals. Yet, the available establishment measures in mown versus grazed sites did not differ from each other. In contrast, the establishment success was increased in S. officinalis in mown versus abandoned sites (Musche et al. 2008). The latter might be explained not only by the lower competition for light in mown sites but also by an increased establishment success of larger seeds as they support the embryos with more nutrients (Westoby et al. 1996).

A higher investment into sexual reproduction might be positively related to the genetic diversity of populations (Leimu et al. 2006) which would be indicated by a similar response of reproduction and genetic diversity. In three of the nineteen species, data on these two traits were available, with a similar positive response in P. alpina (Rudmann-Maurer et al. 2007) and a neutral response in Scabiosa columbaria (Reisch and Poschlod 2009) but different effects in $S$. officinalis (Musche et al. 2008). Yet, for $S$. columbaria the effect also differs if other genetic measures than expected heterozygosity $\left(H_{\mathrm{e}}\right)$ was taken: the percentage of polymorphic loci and Shannon index increase in grazed to mown sites while $H_{\mathrm{e}}$ was unaffected. Slight differences in effect sizes among different genetic diversity measures were recently reported in another metaanalysis (Vranckx et al. 2012). As long as only few data points are available, such differences among related measures might undermine overall effects.

Besides variation in the level of genetic diversity between contrasting management regimes, genetic differentiation and genetic spatial structuring might be affected too. But again, the available data is rather scarce: only one of the analysed studies allowed to calculate a Hedge's $d$ for the differentiation measure and the estimates of spatial genetic structure were indicated either as similarity or dissimilarity measures, which did not allow an input into the meta-analyses per se. Yet, the data available reveals some interesting insights. In $P$. alpina differentiation between similarly managed sites was higher among mown than grazed sites most probably due to seed transport between pastures by livestock (Rudmann-Maurer et al. 2007). Likewise, spatial genetic structure of Bouteloua curtipendula suggested that genetic diversity is homogenized by the livestock grazers (Smith et al. 2009). Homogenizing effects might also occur over time: old Briza media populations had lower levels of internal genetic structure compared to young grasslands probably due to an accumulating effect of internal propagule dispersal (Prentice et al. 2006). A few additional studies reported differentiation measures indicating that differentiation was higher between the two management regimes than among all sites, at least in parts of the genetic markers, suggesting that sites of the same management regime are under converging selection pressure (Mengli et al. 2005; Odat et al. 2004; Reisch and Poschlod 2009).

To sum up, all findings discussed above indicate that differential reproductive success and variable accumulation of genotypes by gene flow over time-in pastures facilitated by a higher availability of seed dispersal vectors (i.e. grazers) - can result in genetic differences between management treatments.

Selection pressure on flowering phenology and plant stature

The removal of the flower stalks before seed set can result in a strong selection pressure for early flowering. So far, flowering phenology was studied only in mown versus grazed 
management regimes and was indeed advanced in the mowing treatment in a number of herbs (Reisch and Poschlod 2009; Poschlod et al. 2000; Zopfi 1993) but not in Euphrasia rostkoviana (Zopfi 1998b). The latter species can be as short as $5 \mathrm{~cm}$ (Lauber and Wagner 1996). Thereby, the mowing treatment might leave the small individuals as well as some flowers of the larger individuals untouched resulting in no selection pressure for flowering phenology but a selection pressure for shorter flowering stalks. Indeed, Zopfi (1998a) reported that individuals from mown sites had shorter stem lengths including inflorescences than from grazed sites. This selection process only works if plants are relatively short per se whereas in taller plants, selection for shorter growth in grazed sites is expected. The re-occurring biomass loss through the grazers might be less severe if the individuals are short as shorter plants might be even missed by the grazers. In grazed compared to mown sites S. columbaria individuals had shorter top peduncles (Reisch and Poschlod 2011) and $P$. alpina produced less biomass (Fischer et al. 2011). In grazed compared to non-grazed sites Elytrigia atherica (Veeneklaas et al. 2011) as well as Agropyron smithii (Cid et al. 1989) reduced shoot length. These results indicate that grazing selects for smaller plants. Thus, selection for shorter stature can occur in meadows if the flower stalk is below the cutting height, whereas in pastures selection seems to favour shorter plants in general-at least in palatable species (see below for unpalatable species). Likewise, occurrence of divergent selection in flowering phenology seems to depend also on the plant stature.

\section{Do life-history traits play a minor role?}

Overall reactions within clonal and non-clonal plants were similar over all plant traits and managements as well as in the mown versus grazed and non-managed versus managed comparison (Figs. 1, 2). However, there are indications that microevolution in non-clonal species might be advanced because their pooled trait groups tended to be affected differently by the management $\left(Q_{\mathrm{b}}=7.58, d f=2, N=11, P=0.078\right)$ while the trait groups did not differ in clonal plants (details not showed). Pooled Hedge's $d$ values for non-clonal plants increasing from genetic to vegetative and reproductive traits $(d=-0.73, \mathrm{CI}-1.60$ to $0.09 ; d=0.14, \mathrm{CI}-0.63$ to 0.71 and $d=2.81$, CI $0.47-5.88$, respectively). For example, S. officinalis produced less seeds (Musche et al. 2008) and longer leaves containing more leaflets (Musche et al. 2010) in abandoned meadows suggesting that selection favours less fecund but more competitive genotypes in the progression of succession (Ronce and Olivieri 1997). A selection pressure for competitiveness might also act on clonal species. Indeed, clone size increased in E. atherica in abandoned sites (Veeneklaas et al. 2011). Yet, clone size of grasses in semiarid areas decreased in non-grazed compared to grazed sites (Liston et al. 2003; Smith 1998; Tomas et al. 2000). Because semiarid areas are generally less productive ecosystems than temperate areas, this finding might indicate that grazing fosters plant growth due to the fertilization by urine and feces (McNaughton and Chapin 1985). Given that the studies on clonal species covered all biomes, while non-clonal species were so far only under study in temperate areas, effect patterns in clonal species might be blurred by other factors, such as differences among biomes. Moreover, clonal grasses can be buffered from environmental change and can persist for centuries (reviewed by de Witte and Stöcklin 2010). Thereby, microevolutionary forces need to be strong to leave a (quantitative) genetic imprint in very long-lived such as clonal plants.

It was expected that the length of the life-cycle influences selection patterns. The analyses revealed no differences (Fig. 1) but the data on the annual life form was derived from only two species which were both hemi-parasites. A firm conclusion can therefore not be drawn. Likewise, the data basis to test for the effect of palatability and non-palatability 
was relatively scares. The overall effect sizes did not differ between palatable and nonpalatable species, but some plant traits suggest contradictory selection patterns. Vegetative growth in the toxic Veratrum album increased ca. fourfold in grazed compared to mown sites (Kleijn and Steinger 2002) whereas grazing selected for smaller plants in palatable species (Fischer et al. 2011; Reisch and Poschlod 2011; Carman and Briske 1985). Toxicity is one of the most effective defense mechanisms against grazers. Other plant defense strategies are tissue silicification which increased in palatable plants of heavily grazed grasslands (McNaughton et al. 1985) or traits associated with defoliation resistance which were selected for in palatable plants of grazed compared to non-grazed areas (Smith 1998; Detling and Painter 1983; Painter et al. 1989). Additionally, nutrient content decreased in plants originating from grazed compared to non-grazed areas indicating lower investment and a reduced value of the tissue for herbivores (Jaramillo and Detling 1988; Polley and Detling 1988). These examples indicate that selection acts on 'defense' mechanisms in relation to grazing in palatable species. In non-palatable species, there are indications that plant evolution is released from the constraints which palatable species underlay.

\section{Conclusion}

No overall selection patterns were found between different management regimes, even though $60 \%$ of the pooled effect sizes and over $70 \%$ of specific effect sizes suggest that the traits are under microevolutionary influences. Generally, it can be assumed that the authors focused on traits which were expected to differ between the management regimes with heterogeneous directions of the effects on the plant measures. Trade-offs among traits within as well as among the three main trait groups might thereby limit the findings of overall effect patterns. But also at the more specific level when individual traits were compared, no general patterns arose. Likewise, life-history traits had no overall effects. Many more species characteristics such as the pollination syndrome, reproductive mode and competitive ability might influence the outcome of the management. Yet, more studies on within species diversity in contrasting managements are needed to disentangle the different effects. Additionally, the main environmental difference between the investigated sites was assumed to be due to the management, but other, unknown factors might induce a selection pressure too. This might be especially the case in the six species and management combinations, where plants of only one site and plot per management type were investigated, while the other 15 combinations might be less affected by unknown factors (Table 2). Thus, the heterogeneous plant reaction might indeed indicate that anthropogenic management, as well as unmanaged grazers, can result in microevolution. Since divergent selection increases within species genetic diversity, the continuation of the different management techniques will contribute to maintain the evolutionary potential of plant species, which is important especially in the face of increasing environmental uncertainties.

Acknowledgments I thank Jaboury Ghazoul, the Subject Editor Camilla Wellstein and the anonymous reviewers for helpful comments on this manuscript.

\section{Appendix}

See Table 3. 


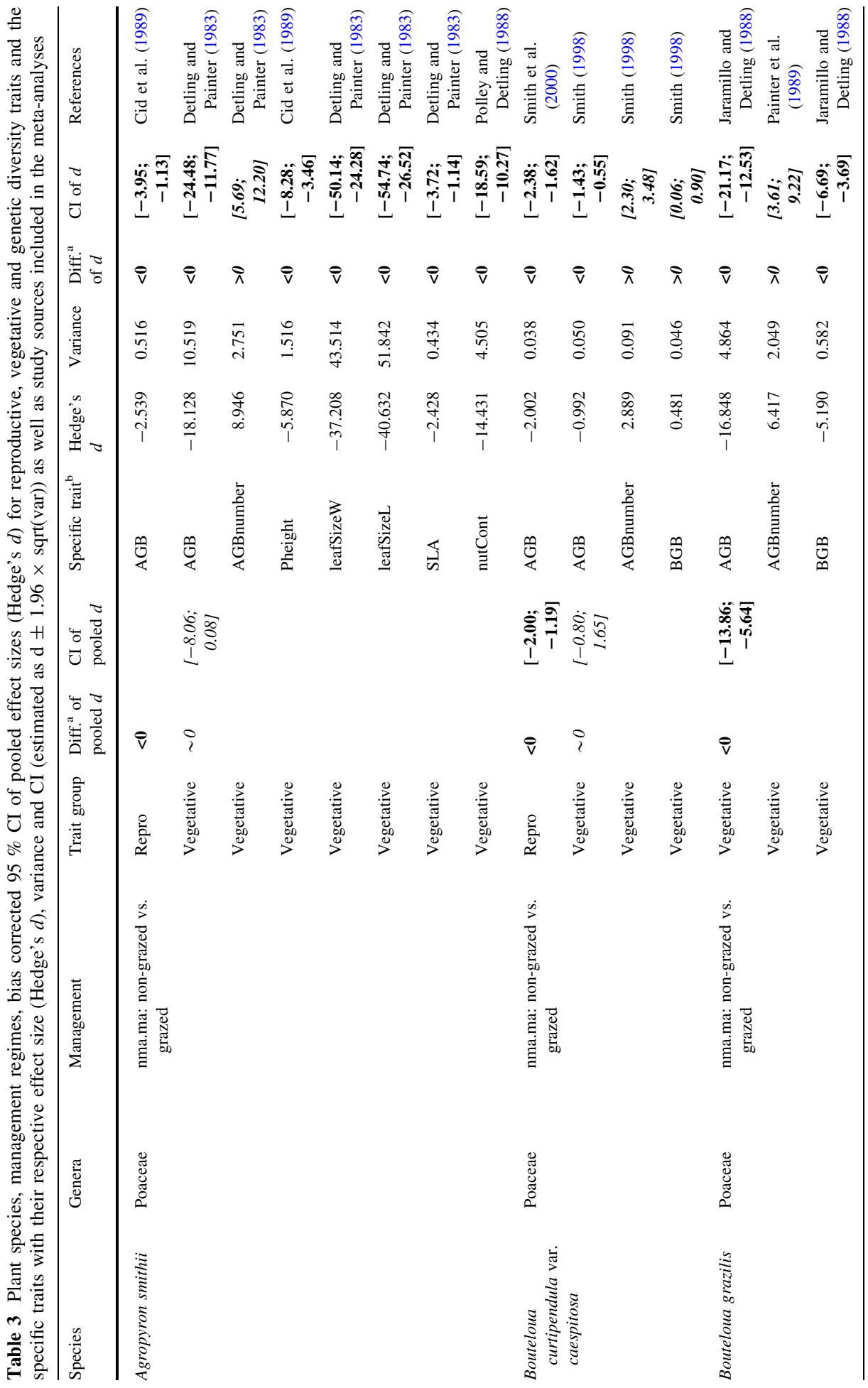




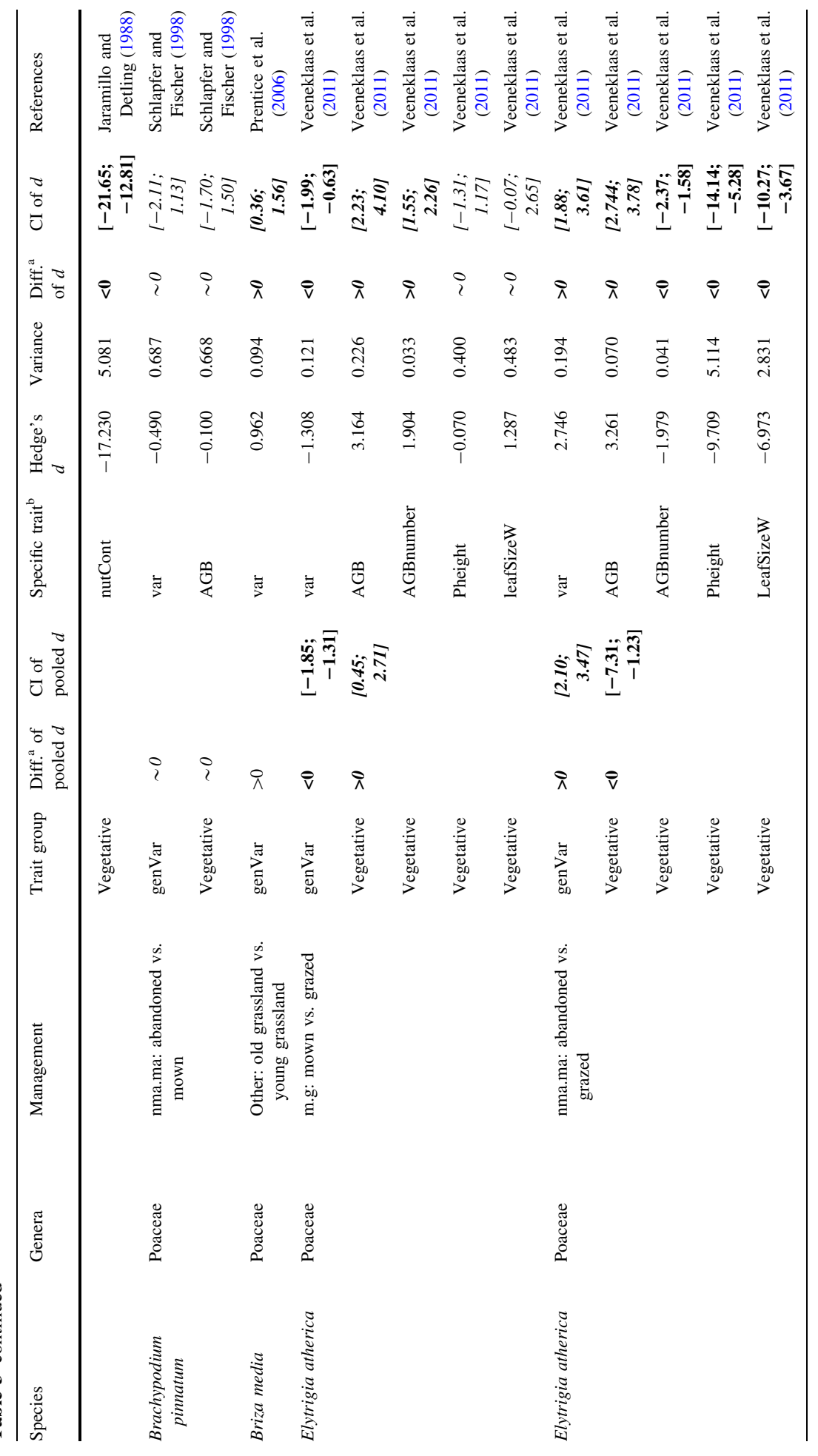




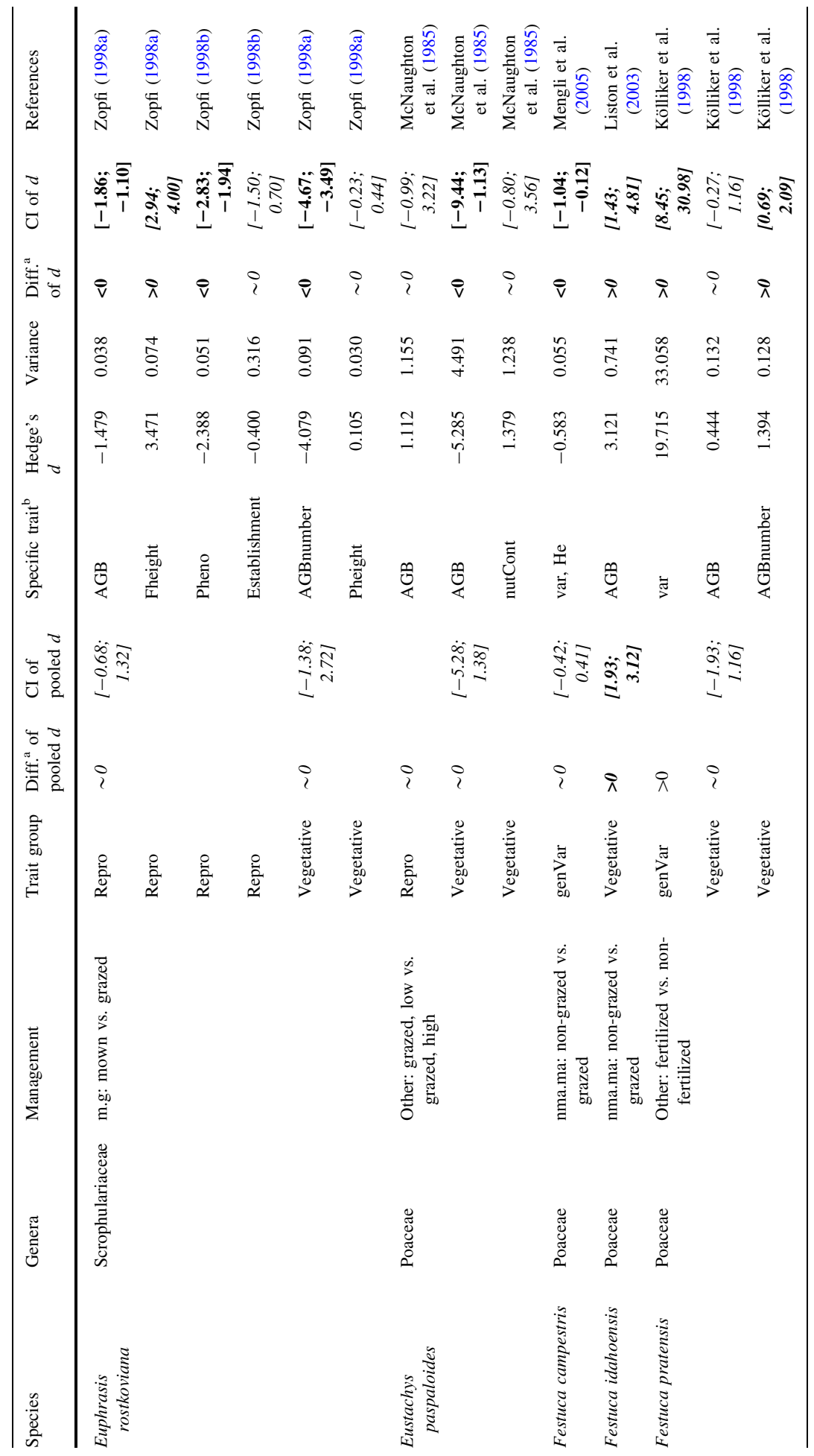




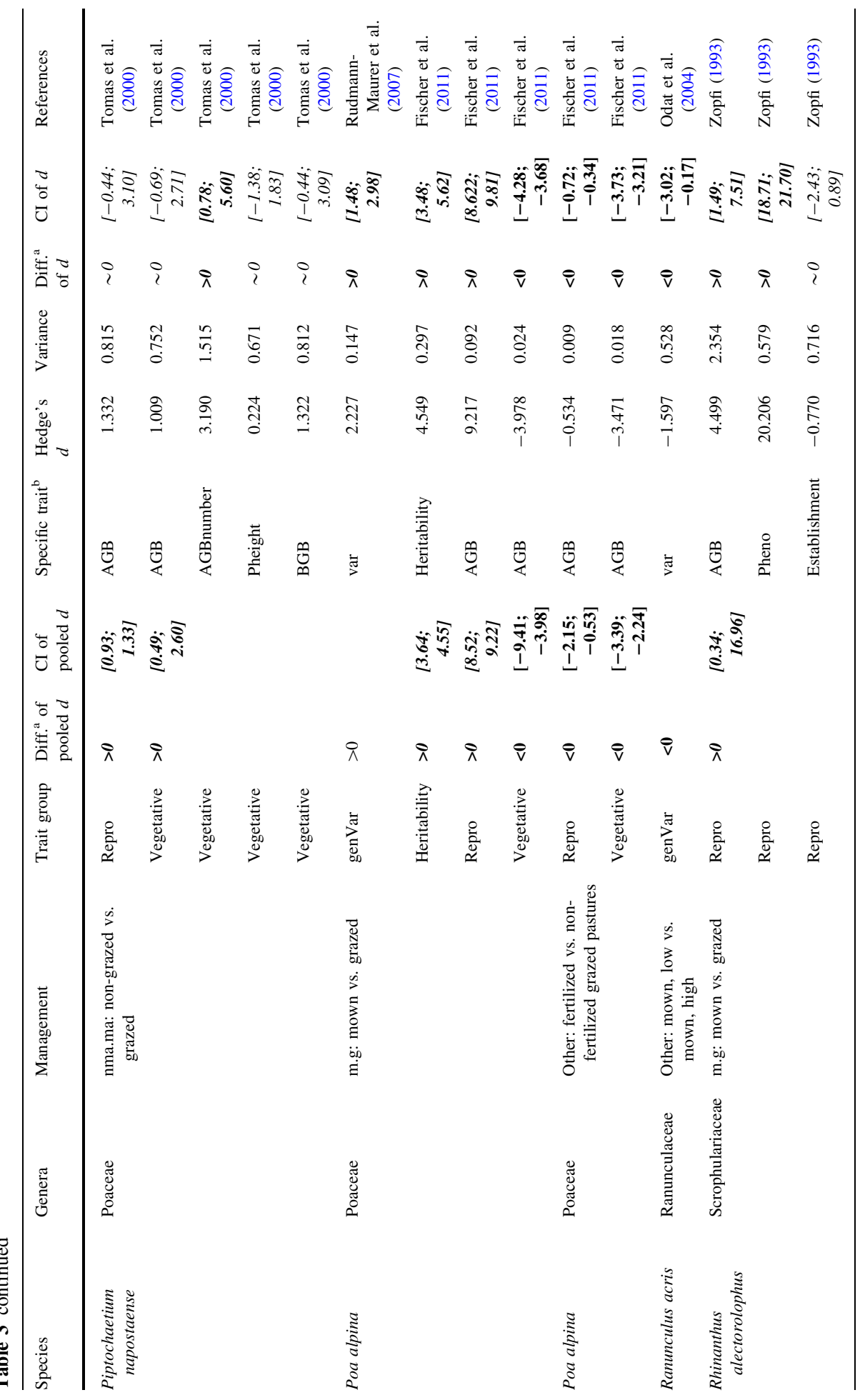




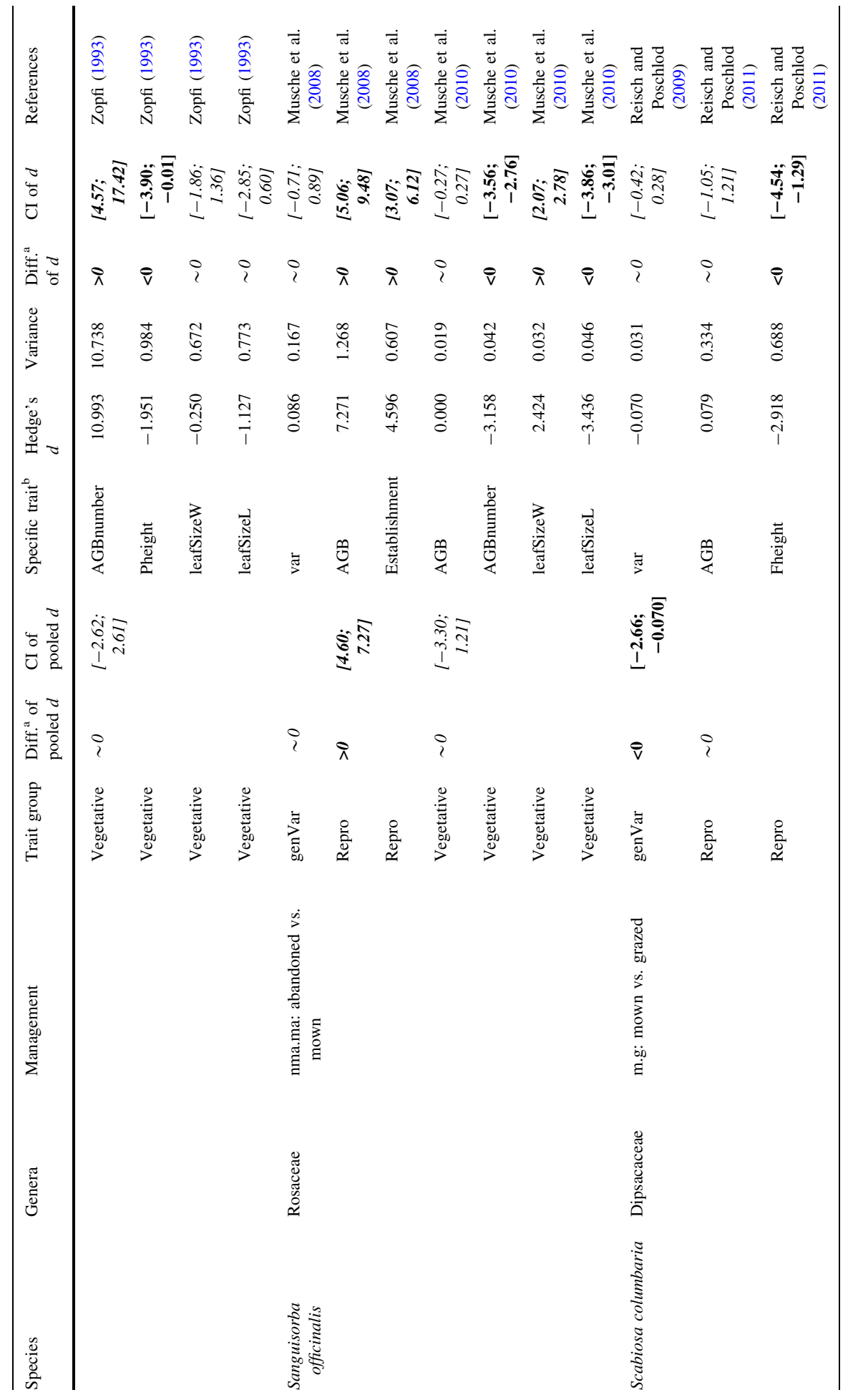




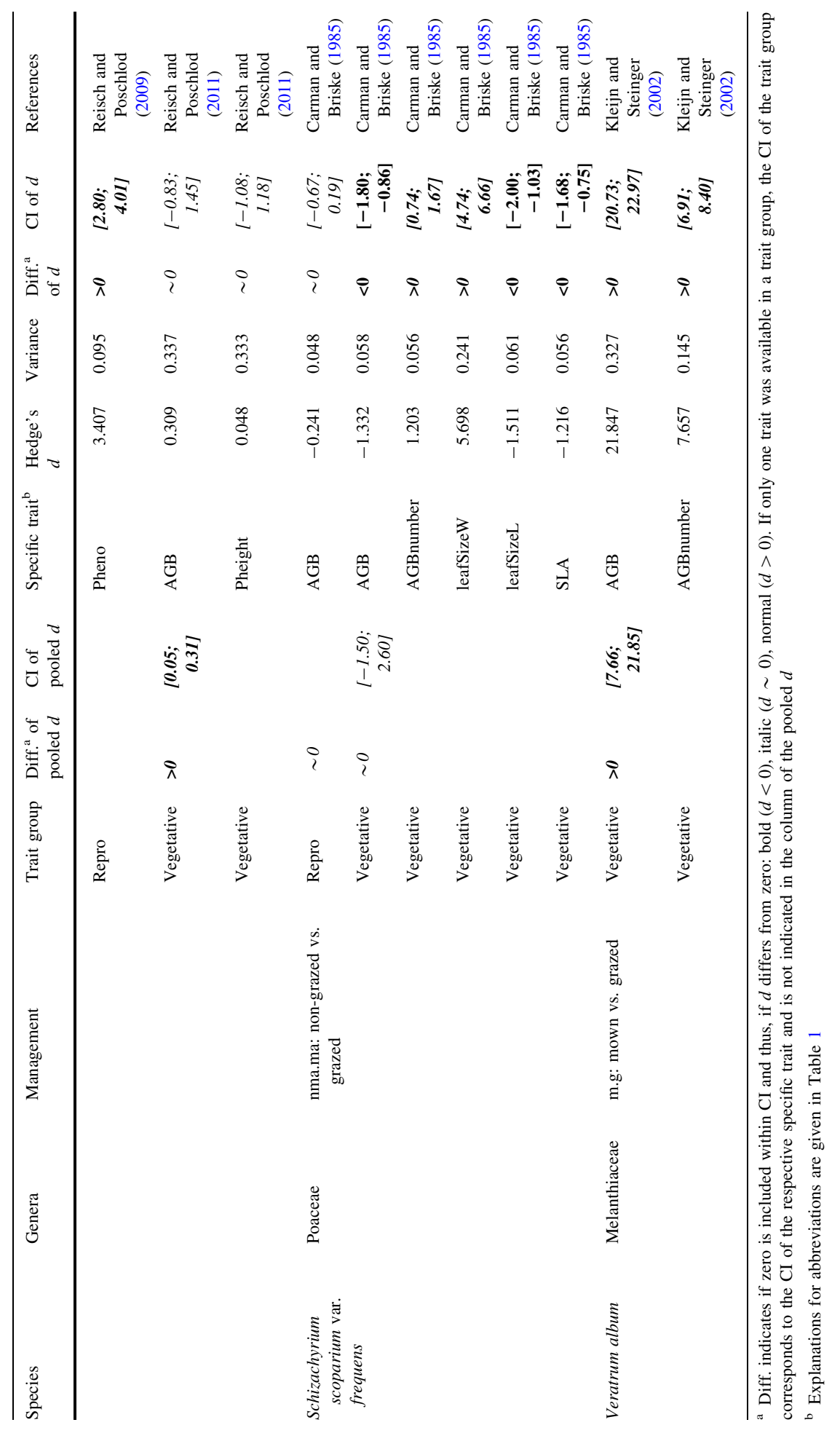




\section{References}

Ashley MV, Willson MF, Pergams ORW, O’Dowd DJ, Gende SM, Brown JS (2003) Evolutionarily enlightened management. Biol Conserv 111(2):115-123

Bätzing W (2003) Die Alpen Geschichte und Zukunft einer europäischen Kulturlandschaft. C.H. Beck, München

Bone E, Farres A (2001) Trends and rates of microevolution in plants. Genetica 112:165-182

Callaghan TV, Emannualson U (1985) Population structure and processes of tundra plants and vegetation. In: White J (ed) The population structure of vegetation. Junk, Dodrecht, pp 399-439

Carman JG, Briske DD (1985) Morphologic and allozymic variation between long-term grazed and nongrazed populations of the bunchgrass Schizachyrium scoparium var. frequens. Oecologia 66(3):332-337

Cid MS, Detling JK, Brizuela MA, Whicker AD (1989) Patterns in grass silicification-response to grazing history and defoliation. Oecologia 80(2):268-271

de Witte LC, Stöcklin J (2010) Longevity of clonal plants: why it matters and how to measure it. Ann Bot 106(6):859-870

Detling JK, Painter EL (1983) Defoliation responses of western wheatgrass populations with diverse histories of prairie dog grazing. Oecologia 57(1-2):65-71

Fischer M, Stöcklin J (1997) Local extinctions of plants in remnants of extensively used calcareous grasslands 1950-1985. Conserv Biol 11(3):727-737

Fischer M, Rudmann-Maurer K, Weyand A, Stocklin J (2008) Agricultural land use and biodiversity in the Alps-how cultural tradition and socioeconomically motivated changes are shaping grassland biodiversity in the Swiss Alps. Mt Res Dev 28(2):148-155

Fischer M, Weyand A, Rudmann-Maurer K, Stöcklin J (2011) Adaptation of Poa alpina to altitude and land use in the Swiss Alps. Alp Bot 121(2):91-105

Fu YB, Thompson D, Willms W, Mackay M (2005) Long-term grazing effects on genetic variability in mountain rough fescue. Rangel Ecol Manag 58(6):637-642

Gurevitch J, Hedges LV (1999) Statistical issues in ecological meta-analyses. Ecology 80(4):1142-1149

Jaramillo VJ, Detling JK (1988) Gazing history, defoliation, and competition-effects on shortgrass production and nitrogen accumulation. Ecology 69(5):1599-1608

Kleijn D, Steinger T (2002) Contrasting effects of grazing and hay cutting on the spatial and genetic population structure of Veratrum album, an unpalatable, long-lived, clonal plant species. J Ecol 90(2):360-370

Kölliker R, Stadelmann FJ, Reidy B, Nosberger J (1998) Fertilization and defoliation frequency affect genetic diversity of Festuca pratensis Huds. in permanent grasslands. Mol Ecol 7(11):1557-1567

Lachat T, Blaser F, Bösch R, Bonnard L, Gimmi U, Grünig A, Roulier C, Sirena G, Stöcklin J, Volkart G (2010) Verlust wertvoller Lebensräume. In: Lachat T, Pauli D, Gonseth Y et al. (eds) Wandel der Biodiversität in der Schweiz seit 1900-Ist die Talsohle erreicht? Zürich, Bristol Stiftung, Haupt, Bern, Stuttgart, Wien, pp 22-63

Lauber K, Wagner G (1996) Flora helvetica. Haupt, Bern

Leimu R, Fischer M (2008) A meta-analysis of local adaptation in plants. PLoS One 3(12):e4010

Leimu R, Mutikainen P, Koricheva J, Fischer M (2006) How general are positive relationships between plant population size, fitness and genetic variation? J Ecol 94(5):942-952

Light RJ, Pillemer DB (1984) Summing up: the science of reviewing research. Harvard University Press, Cambridge

Liston A, Wilson BL, Robinson WA, Doescher PS, Harris NR, Svejcar T (2003) The relative importance of sexual reproduction versus clonal spread in an aridland bunchgrass. Oecologia 137(2):216-225

McNaughton SJ, Chapin FS (1985) Effects of phosphorous nutrition and defoliation on C-4 graminoids from the Serengeti plains. Ecology 66(5):1617-1629

McNaughton SJ, Tarrants JL, McNaughton MM, Davis RH (1985) Silica as a defense against herbivory and a growth promotor in African grasses. Ecology 66(2):528-535

Mengli Z, Willms WD, Bing H, Laroche A (2005) Effects of heavy grazing pressure on the random amplified polymorphic DNA marker diversity of mountain rough fescue (Festuca campestris Rydb.) in south western Alberta. Can J Plant Sci 85(3):623-629

Musche M, Settele J, Durka W (2008) Genetic population structure and reproductive fitness in the plant Sanguisorba officinalis in populations supporting colonies of an endangered Maculinea butterfly. Int J Plant Sci 169(2):253-262

Musche M, Settele J, Durka W (2010) Performance and response to defoliation of Sanguisorba officinalis (Rosaceae) seedlings from mown and successional habitats. Botany 88(7):691-697 
Norton-Griffiths M (1979) The influence of grazing, browsing and fire on the vegetation dynamics of the Serengeti. In: Sinclair ARE, Norton-Griffiths M (eds) Serengeti: dynamics of an ecosystem. University Chicago Press, Chicago, pp 310-352

Odat N, Jetschke G, Hellwig FH (2004) Genetic diversity of Ranunculus acris L. (Ranunculaceae) populations in relation to species diversity and habitat type in grassland communities. Mol Ecol 13(5):1251-1257

Painter EL, Detling JK, Steingraeber DA (1989) Grazing history, defoliation, and frequency-dependent competition-effects on two North-American grasses. Am J Bot 76(9):1368-1379

Palmer AR (1999) Detecting publication bias in meta-analyses: a case study of fluctuating asymmetry and sexual selection. Am Nat 154:220-233

Pico FX, van Groenendael J (2007) Large-scale plant conservation in European semi-natural grasslands: a population genetic perspective. Divers Distrib 13(6):920-926

Polley HW, Detling JK (1988) Herbivory tolerance of Agropyron smithii populations with different grazing histories. Oecologia 77(2):261-267

Poschlod P, WallisDeVries MF (2002) The historical and socioeconomic perspective of calcareous grasslands-lessons from the distant and recent past. Biol Conserv 104(3):361-376

Poschlod P, Dannenmann A, Kahmen S, Melzheimer V, Biedermann H, Mengel C, Neugebauer KR, Pantle I (2000) Genes in the landscape-change in central European land use and its impact on genetic diversity of plants. Schriftenreihe für Vegetationskunde, Bundesamt für Naturschutz, Bonn 32:111-127

Pott R (1996) Die Entwicklungsgeschichte und Verbreitung xerothermer Vegetationseinheiten in Mitteleuropa under dem Einfluss des Menschen. Tuexenia 16:337-369

Prentice HC, Lonn M, Rosquist G, Ihse M, Kindstrom M (2006) Gene diversity in a fragmented population of Briza media: grassland continuity in a landscape context. J Ecol 94(1):87-97

Reisch C, Poschlod P (2009) Land use affects flowering time: seasonal and genetic differentiation in the grassland plant Scabiosa columbaria. Evol Ecol 23(5):753-764

Reisch C, Poschlod P (2011) Morphology and phenology of Scabiosa columbaria from mown and grazed habitats-results of a simulation experiment. Flora 206(10):887-891

Reznick DN, Ghalambor CK (2001) The population ecology of contemporary adaptations: what empirical studies reveal about the conditions that promote adaptive evolution. Genetica 112:183-198

Ronce O, Olivieri I (1997) Evolution of reproductive effort in a metapopulation with local extinctions and ecological succession. Am Nat 150(2):220-249

Rosenberg MS, Adams DC, Gurewitch J (1999) MetaWin: statistical software for meta-analysis, vol version 2.0. Sinauer Associates, Sunderland

Rosenthal R (1979) The "file-drawer problem" and tolerance for null results. Psychol Bull 86:638-641

Rudmann-Maurer K, Weyand A, Fischer M, Stöcklin J (2007) Microsatellite diversity of the agriculturally important alpine grass Poa alpina in relation to land use and natural environment. Ann Bot 100(6): 1249-1258

Savolainen O (2011) The genomic basis of local climatic adaptation. Science 333(6052):49-50

Schlapfer F, Fischer M (1998) An isozyme study of clone diversity and relative importance of sexual and vegetative recruitment in the grass Brachypodium pinnatum. Ecography 21(4):351-360

Schmid B (1990) Some ecological and evolutionary consequences of modular organization and clonal growth in plants. Evol Trends Plants 4(1):25-34

Silvertown J, Charlesworth D (2001) Introduction to plant population biology, 4th edn. Blackwell Science, Oxford, UK

Smith SE (1998) Variation in response to defoliation between populations of Bouteloua curtipendula var. caespitosa (Poaceae) with different livestock grazing histories. Am J Bot 85(9):1266-1272

Smith SE, Mosher R, Fendenheim D (2000) Seed production in sideoats grama populations with different grazing histories. J Range Manage 53(5):550-555

Smith SE, Arredondo T, Aguiar M, Huber-Sannwald E, Alpuche A, Aguado A, Grageda OA, Halbrook K, Bottini C (2009) Fine-scale spatial genetic structure in perennial grasses in three environments. Rangel Ecol Manag 62(4):356-363

Stöcklin J, Bosshard A, Klaus G, Rudmann-Maurer K, Fischer M (2007) Landnutzung und biologische Vielfalt in the Alpen-Thematische Synthese zum Forschungsschwerpunkt II "Land- und Forstwirtschaft im alpinen Lebensraum" des Nationalen Forschungsprogramms NFP 48 "Landschaften und Lebensräume der Alpen” des Schweizerischen Nationalfonds SNF. vdf Hochschulverlag AG, Zürich, Switzerland

Tomas MA, Carrera AD, Poverene M (2000) Is there any genetic differentiation among populations of Piptochaetium napostaense (Speg.) Hack (Poaceae) with different grazing histories? Plant Ecol 147(2):227-235 
Tummers B, van der Laan J, Huyser K (2010) Data Thief III, 1.6 edn. http://www.datathief.org. Accessed June 4, 2012

Veeneklaas R, Bockelmann A, Reusch T, Bakker J (2011) Effect of grazing and mowing on the clonal structure of Elytrigia atherica: a long-term study of abandoned and managed sites. Preslia 83(3): $455-470$

Vranckx G, Jacquemyn H, Muys B, Honnay O (2012) Meta-analysis of susceptibility of woody plants to loss of genetic diversity through habitat fragmentation. Conserv Biol 26(2):228-237

Westoby M, Leishman M, Lord J (1996) Comparative ecology of seed size and dispersal. Philos Trans R Soc Lond Ser B Biol Sci 351(1345):1309-1317

Zopfi HJ (1993) Ecotypic variation in Rhinanthus alectorolophus (Scopoli) Pollich (Scrophulariaceae) in relation to grassland management. II. The genotypic basis of seasonal ecotypes. Flora 188(2):153-173

Zopfi HJ (1998a) The genetic basis of ecotypic variants of Euphrasia rostkoviana Hayne (Scrophulariaceae) in relation to grassland management. Flora 193(1):41-58

Zopfi HJ (1998b) Life-history variation among populations of Euphrasia rostkoviana Hayne (Scrophulariaceae) in relation to grassland management. Biol J Linnean Soc 64(2):179-205 